\title{
Arbeidsmarktprognoses Rivierenland 2017-2022
}

Citation for published version (APA):

Peeters, T., \& Cörvers, F. (2018). Arbeidsmarktprognoses Rivierenland 2017-2022. ROA. ROA Fact

Sheets No. 010F https://doi.org/10.26481/umarof.2018010F

Document status and date:

Published: 01/01/2018

DOI:

10.26481/umarof.2018010F

Document Version:

Publisher's PDF, also known as Version of record

\section{Please check the document version of this publication:}

- A submitted manuscript is the version of the article upon submission and before peer-review. There can be important differences between the submitted version and the official published version of record.

People interested in the research are advised to contact the author for the final version of the publication, or visit the DOI to the publisher's website.

- The final author version and the galley proof are versions of the publication after peer review.

- The final published version features the final layout of the paper including the volume, issue and page numbers.

Link to publication

\footnotetext{
General rights rights.

- You may freely distribute the URL identifying the publication in the public portal. please follow below link for the End User Agreement:

www.umlib.nl/taverne-license

Take down policy

If you believe that this document breaches copyright please contact us at:

repository@maastrichtuniversity.nl

providing details and we will investigate your claim.
}

Copyright and moral rights for the publications made accessible in the public portal are retained by the authors and/or other copyright owners and it is a condition of accessing publications that users recognise and abide by the legal requirements associated with these

- Users may download and print one copy of any publication from the public portal for the purpose of private study or research.

- You may not further distribute the material or use it for any profit-making activity or commercial gain

If the publication is distributed under the terms of Article $25 \mathrm{fa}$ of the Dutch Copyright Act, indicated by the "Taverne" license above, 
Maastricht University $\&$ ROA

\section{Arbeidsmarktprognoses Rivierenland 2017-2022}

Tim Peeters

Frank Cörvers

\section{ROA Fact Sheet}

ROA-F-2018/10F

Researchcentrum voor Onderwijs en Arbeidsmarkt | ROA Research Centre For Education and the Labour Market / ROA 


\section{Arbeidsmarktprognoses Rivierenland 2017-2022}

Inleiding

Als onderdeel van het Project Onderwijs-Arbeidsmarkt (POA) stelt het ROA sinds 2013 tweejaarlijkse regionale arbeidsmarktprognoses op die tegemoet komen aan de toenemende belangstelling voor regionale arbeidsmarktinformatie. Binnen dit kader past ook voorliggende factsheet met arbeidsmarktprognoses voor de arbeidsmarktregio Rivierenland. Deze prognoses bestrijken de periode 2017-2022 en worden weergegeven voor 24 opleidingscategorieën die verdeeld zijn over zes opleidingsniveaus. Waar mogelijk worden de prognoses vergeleken met deze voor Gelderland als geheel, en wordt er een relatie gelegd met zowel de sector- als opleidingsspecialisatie van de werkgelegenheid in de verschillende regio's. De interpretatie van de prognoses gebeurt steeds vanuit het perspectief van schoolverlaters en werkzoekenden.

De prognoses voor de hele provincie Gelderland evenals een leeswijzer kunnen gevonden worden in de factsheet met nummer ROA-F-20I8/Io. Onderstaande kaart geeft aan hoe Gelderland is samengesteld uit de verschillende arbeidsmarktregio's, en de overzichtstabel laat de verschillende gemeenten zien die in Rivierenland gelegen zijn. Zie ten slotte Tekstbox I voor definities van de in deze factsheet gebruikte variabelen.

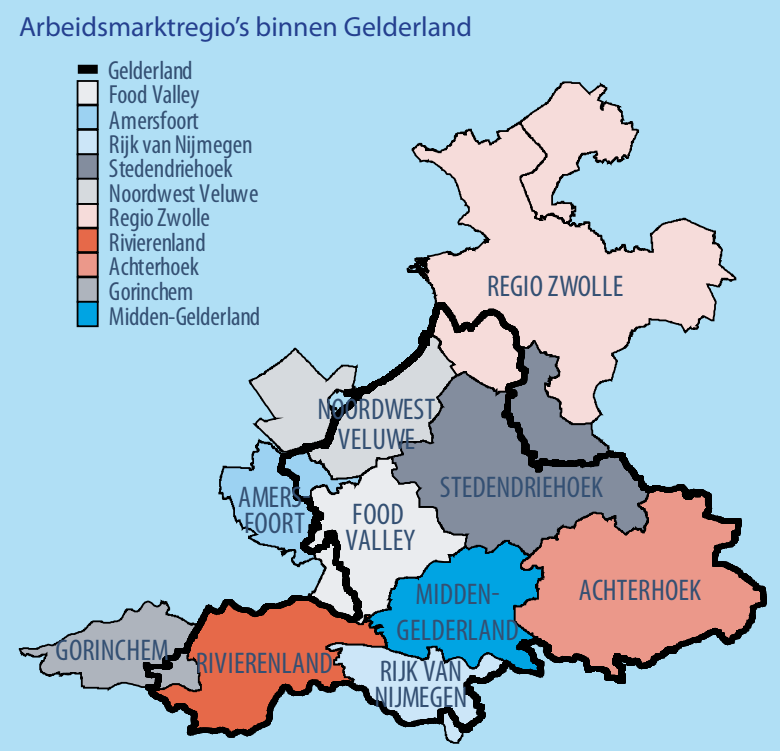

Gemeenten in Rivierenland

Buren

Culemborg

Geldermalsen

Maasdriel

Neder-Betuwe

Neerijnen

Tiel

West Maas en Waal

Zaltbommel
Prognoses en actuele arbeidsmarktcijfers naar opleidingsniveau

Met III.50o werkenden is Rivierenland de kleinste van de zeven Gelderse regio's. Op geaggregeerd niveau wordt tussen 2017 en 2022 met een ITA van 0,99 een klein vraagoverschot verwacht (zie tabel I). ${ }^{.}$Dit geldt eveneens voor alle opleidingsniveaus behalve mbo $2 / 3$ en mbo 4 , welke slechts matige perspectieven hebben die in lijn liggen van deze van de provincie. De vooruitzichten voor wo zijn significant beter dan deze voor Gelderland als geheel, wat gedreven wordt door zowel een hoge vervangingsvraag als een hoge uitbreidingsvraag. Daarnaast zal ook havo/vwo naar verwachting een relatief grote vraag kennen, wat maakt dat Rivierenland de beste perspectieven voor dit opleidingsniveau kent.

Met betrekking tot de actuele arbeidsmarktindicatoren valt op dat, afgezien van wo, alle opleidingsniveaus hier een grotere werkzaamheid kennen dan het Gelderse gemiddelde. Dit geldt in het bijzonder voor havo/vwo $(67 \%)$ en mbo $2 / 3$ (71\%). In vergelijking met de andere arbeidsmarktregio's werken schoolverlaters van het basisonderwijs en vmbo in Rivierenland bovendien het vaakst voltijds (50\%). Ook wo-gediplomeerden werken vaker voltijds, maar zijn gemiddeld ouder dan het provinciale gemiddelde.

Opvallend is dat de verwachte ITA voor basisonderwijs en vmbo $(0,93)$ bijna even gunstig is als deze voor wo $(0,90)$. Dit is een gevolg van de relatief grote vervangingsvraag en vrij kleine arbeidsmarktinstroom vanuit het basisonderwijs of vmbo (veelal voortijdig schoolverlaters van vmbo, mbo of havo/vwo). Deze gunstige perspectieven dienen echter met enige voorzichtigheid geïnterpreteerd te worden. Een aanzienlijk deel van de vraag naar personen met basisonderwijs of vmbo als opleidingsachtergrond heeft namelijk betrekking op laagbetaalde en kleine banen. Dit kan afgeleid worden van het relatief lage uurloon ( 13,7 euro), het lage gemiddeld aantal gewerkte uren per week $(25,5)$ en het hoge aandeel van studenten en scholieren (24\%). Bovendien gaat het vaak om flexibele banen met weinig doorgroeimogelijkheden. Enerzijds blijkt dit uit het lage percentage dat voltijds en vast in dienst is. Anderzijds komt dit ook tot uiting in het slechte loopbaanperspectief. De variabele "typering loopbaan", die per opleidingsniveau de loongroei tussen ca. 25 en 45 jaar (berekend voor Nederland als geheel) weergeeft in 2016, is namelijk het minst gunstig voor laagopgeleiden, en het meest gunstig voor havo/vwo. ${ }^{2}$ Deze laatste groep bestaat mogelijk

I Merk op dat Rivierenland een sterke oriëntatie heeft op steden buiten de regio, wat leidt tot omvangrijke ingaande en uitgaande pendelstromen.

2 De indicator voor loopbaanperspectief wordt berekend aan de hand van het verschil in bruto uurloon van werkenden in de leeftijdsgroep 20-29 jaar en 40-49 jaar. Voor een argumentatie, zie Fouarge, D., Kriechel, B., \& Dohmen, T. (20I4), Occupational sorting of school graduates: The role of economic preferences, Journal of Economic Behavior \& Organization, I06, $335-35$ I. 
deels uit mensen die geen hogere opleiding hebben afgemaakt omdat ze door hun persoonlijke capaciteiten uitstekende kansen op de arbeidsmarkt hadden.

Verder is van belang dat de groep van laagopgeleiden met basisonderwijs of vmbo heel heterogeen is: niet alleen scholieren, maar ook voortijdig schoolverlaters zonder startkwalificatie (minimaal mbo 2 of havo), schoolverlaters van het speciaal onderwijs en arbeidsgehandicapten. Bij het aangegeven goede arbeidsmarktperspectief is geen rekening gehouden met de mogelijke sociale, fysieke en cognitieve beperkingen van mensen binnen deze groep.

\section{Sectorspecialisatie}

Figuur I, die de sectorspecialisatie ${ }^{3}$ van Rivierenland toont, wordt gedomineerd door de specialisatie in de sector landbouw, bosbouw en visserij, waarvan het werkgelegenheidsaandeel bijna drie maal groter is dan het Nederlandse. Dit gaat gepaard met specialisaties in de metaal- en overige industrie, hoewel slechts in mindere mate in vergelijking met de Achterhoek. Andere sectoren met een groot werkgelegenheidsaandeel in Rivierenland zijn de bouwnijverheid, groothandel, detailhandel en vervoer en opslag. Opvallend is dat de welzijnssector en de zorgsector sterk ondervertegenwoordigd zijn ten opzichte van zowel Gelderland en Nederland. Hetzelfde geldt voor de energiesector, cultuur, sport en recreatie en openbaar bestuur en overheidsdiensten.

\section{Arbeidsmarktperspectieven naar opleidingscategorie}

De prognoses naar opleidingsniveau uit de eerste paragraaf kunnen verder uitgesplitst worden naar opleidingscategorie. Dit is weergegeven in Figuur 2, die per opleidingscategorie binnen het lager en middelbaar (beroeps)onderwijs toont hoe de totale arbeidsvraag en het totale arbeidsaanbod zich naar verwachting de komende zes jaar in Rivierenland zullen verhouden. Figuur 3 doet hetzelfde voor het hoger onderwijs.

De kleuren bakenen de gebieden af die corresponderen met de vijf eerder besproken ITA-typeringen voor schoolverlaters, gaande van slecht (rood en ITA > I,I5) tot zeer goed (grijs en ITA $\leq 0,85$ ). Deze kunnen geïnterpreteerd worden als een kwalitatieve aanduiding van de verwachte arbeidsmarktperspectieven. Voor de punten op de middelste diagonale lijn zijn verwachtevraag en aanbod aan elkaar gelijk, wat correspondeert met een ITA gelijk aan I. Bijvoorbeeld, voor hbo techniek bedragen het totale aanbod en de totale vraag over zes jaar respectievelijk (afgerond) 22\% en 38\%. Deze waarden impliceren een ITA van 0,89 , zodat hbo

3 Gebaseerd op de werkzame beroepsbevolking uit de Enquête Beroepsbevolking (EBB), inclusief zelfstandigen. techniek zich bevindt in het donkerblauwe gedeelte met het perspectief "goed". ${ }^{4}$ Merk op dat deze ITA een gemiddelde betreft van de opleidingscategorie hbo techniek, en dat er variatie kan bestaan in de arbeidsmarktperspectieven van de onderliggende opleidingstypes.

De vraag- en aanbodprognoses voor de opleidingscategorieën in het lager en middelbaar (beroeps) onderwijs voor de komende zes jaar, weergegeven in Figuur 2, komen sterk overeen met die van Gelderland. Afgestudeerden van mbo $2 / 3$ groen hebben de slechtste vooruitzichten vanwege een lage uitbreidings- en vervangingsvraag, terwijl de arbeidsmarktperspectieven voor schoolverlaters van mbo 4 groen redelijk is als gevolg van een aanzienlijk kleiner arbeidsaanbod. Met betrekking tot beide opleidingscategorieën worden voor de sector landbouw, bosbouw en visserij bijgevolg weinig rekruteringsmoeilijkheden verwacht. De detail- en groothandel, waarin Rivierenland eveneens gespecialiseerd is, zullen daarentegen naar verwachting wel te maken krijgen met knelpunten, met name voor schoolverlaters van het basisonderwijs/vmbo en het havo/vwo.

Figuur 3 die de prognoses voor de hogere opleidingscategorieën toont, wordt sterk vertekend door wo medisch. Voor schoolverlaters van deze opleidingscategorie wordt er tussen 2017 en 2022 zowel een erg grote arbeidsvraag als een erg groot arbeidsaanbod verwacht. De vraagcomponent wordt daarbij gedreven door een sterke uitbreidingsvraag (gemiddeld $5 \%$ per jaar) en een hoge vervangingsvraag (gemiddeld $\mathrm{II} \%$ per jaar). De aanbodcomponent wordt voor een aanzienlijk deel gedreven door een grote verwachte instroom vanuit andere arbeidsmarktregio's. Langs de vraagzijde is eveneens wo techniek een uitbijter, waarvan de afgestudeerden met een ITA van 0,73 op de Achterhoek na de beste arbeidsmarktperspectieven in Gelderland hebben. Dit vraagoverschot komt door een zeer hoge vervangingsvraag van bijna IO\% per jaar.

Binnen het hbo worden voor schoolverlaters van alle opleidingscategorieën minstens redelijke arbeidsmarktperspectieven voorzien, behalve voor hbo economie en hbo taal en cultuur (matig). De matige vooruitzichten voor afgestudeerden van hbo economie zijn echter in geen enkele andere arbeidsmarktregio beter. Ook schoolverlaters van hbo gedrag en maatschappij hebben in geen enkele andere arbeidsmarktregio betere perspectieven. Beide opleidingscategorieën worden echter hoofdzakelijk gevraagd in sectoren waarin Rivierenland een relatief kleine werkgelegenheid heeft ten opzichte van Nederland.

4 De berekening van de ITA is niet louter een deling van aanbod en vraag, aangezien teller en noemer nog dienen vermeerderd te worden met Ioo. 
Relatie arbeidsmarktperspectieven en specialisatie naar opleiding

Figuur 4 toont de relatie tussen de verwachte arbeidsmarktperspectieven (ITA) voor de verschillende opleidingscategorieën over de periode 20I7-2022 en de mate waarin Rivierenland in deze opleiding "gespecialiseerd" is. Deze laatste variabele is gelijk aan de ratio van het aandeel werkzame personen met een bepaalde opleidingscategorie die in Rivierenland wonen ten opzichte van het aandeel van die opleidingscategorie in het Nederlandse totaal. Indien de specialisatiecoëfficiënt voor een opleidingscategorie groter is dan I,Oo, betekent dit dus dat Rivierenland in verhouding tot Nederland een groter aandeel van mensen met deze opleiding kent. Bijvoorbeeld, de opleidingsspecialisatiecoëfficiënt van I,I9 die hoort bij mbo 4 economie impliceert dat het aandeel van deze opleidingscategorie in Rivierenland $19 \%$ groter is dan het aandeel van deze opleidingscategorie in Nederland als geheel. Arbeidsmarkttekorten zijn ernstiger naarmate de specialisatiegraad van de werkgelegenheid voor de betreffende opleidingscategorieën in een regio groter is. De figuur laat zien dat de meeste mbo-opleidingen matige arbeidsmarktperspectieven en een relatief groot aandeel werkenden ten opzichte van Nederland kennen. Het omgekeerde geldt meestal voor de hogere opleidingen. De twee opleidingen die het grootste aandeel werkenden kennen in verhouding tot Nederland zijn mbo 2/3 groen en mbo 4 groen, hetgeen samenhangt met de omvang van de sector landbouw, bosbouw en visserij. Het Rivierenlandse aandeel van mbo $2 / 3$ groen is daarbij beduidend groter in vergelijking met Nederland, en haar ITA aanzienlijk slechter. Dit verschilt van de situatie in de Achterhoek waar de specialisatie in mbo 4 groen significant groter is.

Net als in de Achterhoek zijn er in Rivierenland relatief weinig hoger opgeleiden. Dit geldt in het bijzonder voor wo medisch, waarvan het aandeel in deze arbeidsmarktregio bijna zeven keer kleiner is dan dat van Nederland. De uitzonderlijk grote verwachte arbeidsvraag en -aanbod voor deze opleidingscategorie in Figuur 3 heeft met andere woorden betrekking op relatief weinig personen. Hetzelfde geldt voor wo techniek. Aan hbo-zijde valt op dat hbo taal en cultuur beide ongunstige ITA's hebben en tegelijkertijd relatief weinig voorkomen in deze arbeidsmarktregio.

Tekstbox 1 Definities kernbegrippen

\begin{tabular}{|c|c|}
\hline Variabele & Definitie \\
\hline Uitbreidingsvraag & $\begin{array}{l}\text { Vraag naar nieuwe arbeidskrachten die ontstaat door de groei van de werkgelegenheid. Als er sprake is van een werkgelegenheidsdaling, is de uitbreidingsvraag } \\
\text { negatief. }\end{array}$ \\
\hline Vervangingsvraag & $\begin{array}{l}\text { Vervangingsvraag is de vraag naar nieuwe arbeidskrachten die ontstaat door bijvoorbeeld pensionering, (tijdelijke) uittreding vanwege zorgtaken, } \\
\text { arbeidsongeschiktheid, beroepsmobiliteit of doorstroom naar een andere opleiding. }\end{array}$ \\
\hline Arbeidsmarktuitstroom & De som van de vervangingsvraag en de negatieve uitbreidingsvraag. \\
\hline Arbeidsmarktinstroom & $\begin{array}{l}\text { De arbeidsmarktinstroom is het verwachte aanbod van nieuwe arbeidskrachten op de arbeidsmarkt. Deze is gebaseerd op de verwachte uitstroom van } \\
\text { schoolverlaters uit het initiële dag-, deeltijd-, niet-reguliere voltijdonderwijs en de beroepsgerichte volwasseneneducatie. Het weergegeven aanbod in de figuren } \\
2 \text { en } 3 \text { is de instroom. Gecorrigeerd voor mobiliteitsstromen tussen arbeidsmarktregio's. }\end{array}$ \\
\hline Baanopeningen & $\begin{array}{l}\text { Baanopeningen zijn de totale vraag naar nieuwkomers op de arbeidsmarkt, zoals deze is bepaald door de werkgelegenheidsgroei (positieve uitbreidingsvraag) } \\
\text { en de vervangingsvraag. In de figuren } 2 \text { en } 3 \text { is dit de vraag naar arbeid. }\end{array}$ \\
\hline ITA & $\begin{array}{l}\text { Indicator Toekomstige Arbeidsmarktperspectief (ITA) van schoolverlaters en werkzoekenden. Deze indicator is gelijk aan een deling van het verwachte aanbod } \\
\text { door de verwachte vraag tot 2022. Naarmate de waarde van de ITA hoger ligt, is er sprake van een slechter arbeidsmarktperspectief. Een waarde tussen 1,01 en } \\
\text { 1,05 duidt op een evenwichtssituatie. }\end{array}$ \\
\hline Typering ITA & $\begin{array}{l}\text { Een kwalitatieve beschrijving van de ITA. ITA } \leq 0,85 \text { wordt als "zeer goed" getypeerd, ITA >0,85 en } \leq 1,00 \text { als "goed", ITA > 1,00 en } \leq 1,05 \text { als "redelijk", ITA > } \\
1,05 \text { en } \leq 1,15 \text { als "matig" en ITA }>1,15 \text { als "slecht". }\end{array}$ \\
\hline Typering loopbaan & $\begin{array}{l}\text { Het bruto uurloon van werkenden in de leeftijdsgroep } 40-49 \text { jaar ten opzichte van het bruto uurloon van werkenden in de leeftijdsgroep } 20-29 \text { jaar. Gemiddelde } \\
\text { cijfers voor Nederland in } 2016 .\end{array}$ \\
\hline Bruto uurloon & $\begin{array}{l}\text { Gemiddeld bruto uurloon van werknemers in euro's. Enquête Beroepsbevolking (EBB) gekoppeld aan het Sociaal Statistisch Bestand (SSB) van het jaar } 2016 . \\
\text { Gemiddelde cijfers voor Nederland in } 2016 .\end{array}$ \\
\hline Werkenden & Minimaal 1 uur werkzaam per week en in de leeftijd 15-74. Cijfers op basis van de Enquête Beroepsbevolking van het CBS. \\
\hline Werkzaamheid & Het percentage werkzaam is de werkzame beroepsbevolking als percentage van de potentiële beroepsbevolking (iedereen ouder dan 15 en jonger dan 75 jaar). \\
\hline Werkloosheid & $\begin{array}{l}\text { Percentage personen die geen betaald werk hebben, wel recent hebben gezocht en daarvoor direct beschikbaar zijn als percentage van de totale } \\
\text { beroepsbevolking (werkzaam en werkloos). }\end{array}$ \\
\hline Vast werk & Personen met een vast dienstverband. Percentage op basis van werknemers in de werkzame beroepsbevolking. \\
\hline Voltijds & Voltijdarbeid betreft personen die minstens 35 uur per week werkzaam zijn. Percentage op basis van de werkzame beroepsbevolking. \\
\hline Leeftijd & Gemiddelde leeftijd. \\
\hline Uren & Gemiddeld aantal uren werk per week. \\
\hline Student/scholier & Percentage van de werkenden met maatschappelijke positie student/scholier. \\
\hline Sectorspecialisatie & $\begin{array}{l}\text { De verhouding tussen het aandeel van het aantal werkenden in een sector in een bepaalde regio ten opzichte van het aandeel van die sector in Nederland. Een } \\
\text { sectorspecialisatiecoëfficiënt groter dan } 1 \text { impliceert dat het aandeel werkenden in de desbetreffende sector in de regio groter is dan in Nederland als geheel. }\end{array}$ \\
\hline Opleidingsspecialisatie & $\begin{array}{l}\text { De ratio van het aandeel personen met een bepaalde opleidingscategorie die wonen in een bepaalde regio ten opzichte van het aandeel van die } \\
\text { opleidingscategorie in het Nederlandse totaal. Indien de specialisatiecoëfficiënt voor een opleidingscategorie groter is dan 1, betekent dit dat de regio in } \\
\text { verhouding tot Nederland een groter aandeel van mensen met deze opleiding kent. }\end{array}$ \\
\hline
\end{tabular}


Tabel 1

Arbeidsmarktprognoses (2017-2022) en actuele arbeidsmarktcijfers (2015-2016) Rivierenland (RIVIER) en Gelderland (GLD) naar opleidingsniveau*

\begin{tabular}{|c|c|c|c|c|c|c|c|}
\hline & bo/vmbo & havo/vwo & mbo $2 / 3$ & mbo 4 & hbo & wo & totaal \\
\hline \multicolumn{8}{|l|}{ Prognoses } \\
\hline Uitbreidingsvraag (\%) & 0,6 & 0,8 & 0,7 & 0,7 & 0,7 & 1,1 & 0,7 \\
\hline Vervangingsvraag (\%) & 3,0 & 2,0 & 2,1 & 1,8 & 3,4 & 4,2 & 2,7 \\
\hline Arbeidsmarktinstroom (\%) & 1,7 & 1,8 & 3,8 & 3,3 & 3,7 & 2,1 & 2,8 \\
\hline ITA (RIVIER) & 0,93 & 0,97 & 1,08 & 1,07 & 0,99 & 0,90 & 0,99 \\
\hline Typering ITA (RIVIER) & goed & goed & matig & matig & goed & goed & goed \\
\hline ITA (GLD) & 0,93 & 1,04 & 1,07 & 1,08 & 1,04 & 0,99 & 1,01 \\
\hline Typering ITA (GLD) & goed & redelijk & matig & matig & redelijk & goed & redelijk \\
\hline Typering loopbaan (NL) ${ }^{* *}$ & slecht & zeer goed & matig & redelijk & redelijk & goed & - \\
\hline \multicolumn{8}{|l|}{ Actuele indicatoren } \\
\hline Bruto uurloon (NL)** & 13,7 & 17,3 & 17,7 & 19,2 & 25,1 & 34,7 & -. \\
\hline Werkenden & 32.000 & 6.500 & 22.000 & 21.000 & 19.000 & 9.500 & 111.500 \\
\hline Werkzaamheid (\%) & 50 & 67 & 71 & 83 & 80 & 81 & 66 \\
\hline Werkloosheid (\%) & 4 & 5 & 4 & 4 & 3 & 4 & 4 \\
\hline Vast werk (\%) & 69 & 60 & 87 & 86 & 91 & 94 & 81 \\
\hline Voltijds (\%) & 50 & 30 & 59 & 56 & 58 & 60 & 54 \\
\hline Uren & 29,2 & 22,4 & 33,4 & 33,0 & 33,9 & 34,2 & 31,6 \\
\hline Student/scholier (\%) & 19 & 37 & 1 & 3 & 2 & 0 & 9 \\
\hline
\end{tabular}

"Prognoses als gemiddeld jaarlijks percentage van de werkzame beroepsbevolking in 2016; actuele indicatoren als percentage van de werkzame, totale of potentiële beroepsbevolking 2015-2016 (zie Tekstbox 1), tenzij anders aangegeven

** Lonen voor Nederland in 2016

Figuur 1

Actuele sectorspecialisatie Rivierenland ten opzichte van Nederland en Gelderland (gemiddeld over 2015-2016)

Landbouw, bosbouw en visserij Voedings- en genotmiddelenindustrie

Chemische industrie

Metaalindustrie

Overige industrie Energie

Bouwnijverheid Detailhandel

Groothandel Vervoer en opslag Horeca

Informatie en communicatie Financiële dienstverlening en onroerend goed Specialistische zakelijke dienstverlening

Verhuur en overige zakelijke dienstverlening Openbaar bestuur en overheidsdiensten Onderwijs Zorg Welzijn

Cultuur sport en recreatie Overige dienstverlening, huishoudens en extraterritoriale organisaties

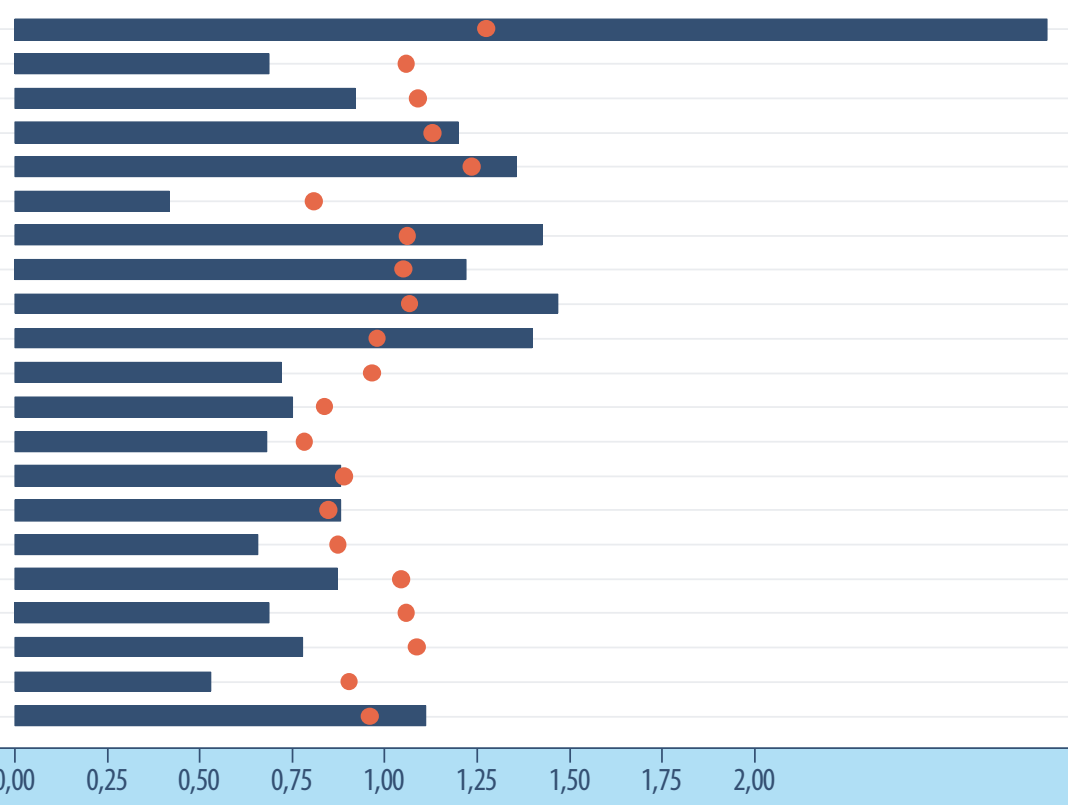

\begin{tabular}{|l|}
\hline Sectorspecialisatie Rivierenland \\
Sectorspecialisatie Gelderland
\end{tabular}


Figuur 2

Vraag en aanbod voor opleidingscategorieën lager/middelbaar (beroeps)onderwijs, Rivierenland (2017-2022)

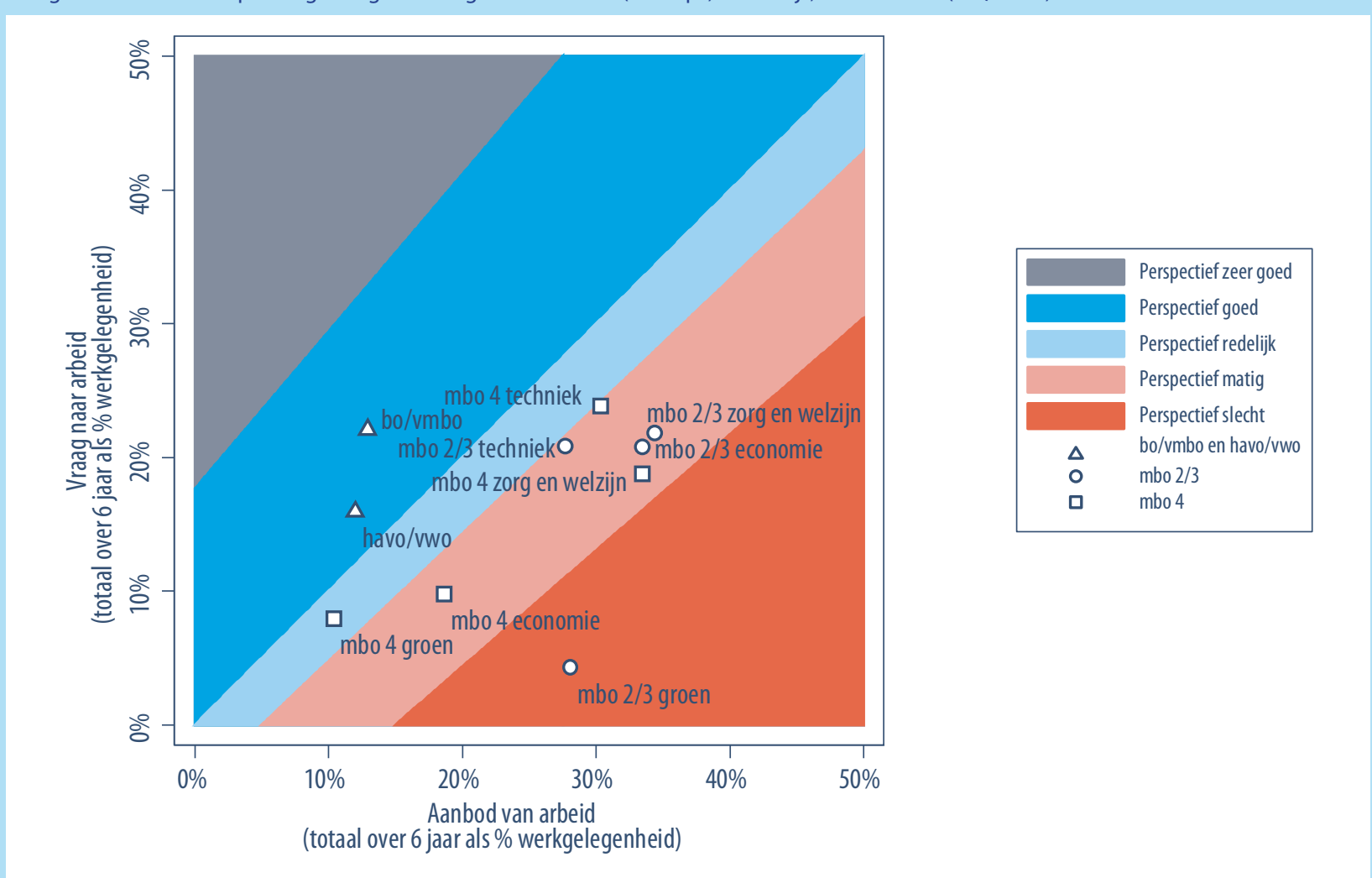

Figuur 3

Vraag en aanbod voor opleidingscategorieën hoger onderwijs, Rivierenland (2017-2022)

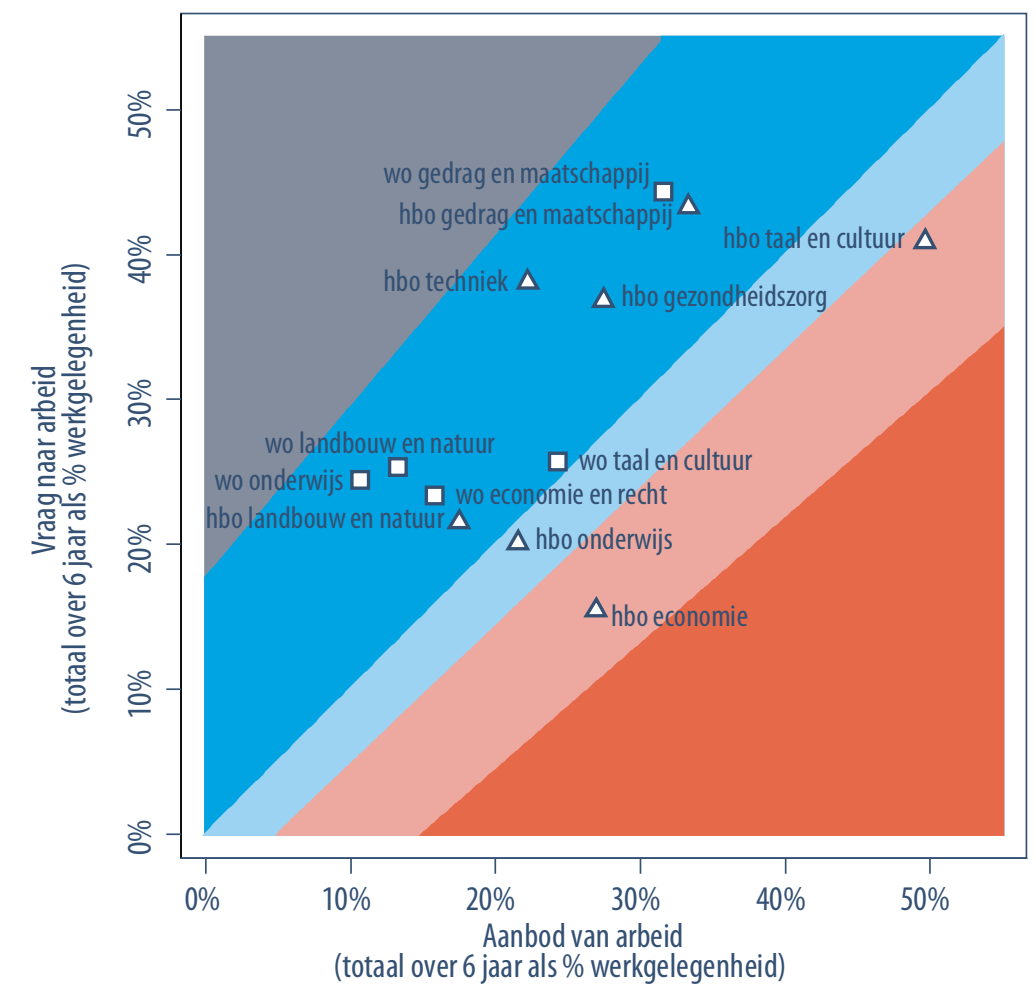

\begin{tabular}{|ll|}
\hline & Perspectief zeer goed \\
\hline & Perspectief goed \\
& Perspectief redelijk \\
& Perspectief matig \\
& Perspectief slecht \\
& hbo \\
$\mathbf{\Delta}$ & wo \\
\hline
\end{tabular}

Noot: Om de leesbaarheid van de figuur te vergroten zijn twee uitschieters weggelaten. Enerzijds betreft het wo techniek, die een ITA heeft van o,73 gebaseerd op een totale vraag van $87 \%$ en een totaal aanbod van $35 \%$. Anderzijds betreft het wo medisch, die een ITA heeft van 0,90 gebaseerd op een totale vraag van $124 \%$ en een totaal aanbod van $100 \%$. 


\section{Figuur 4}

Arbeidsmarktperspectieven (ITA) versus specialisatie naar opleidingscategorie, Rivierenland

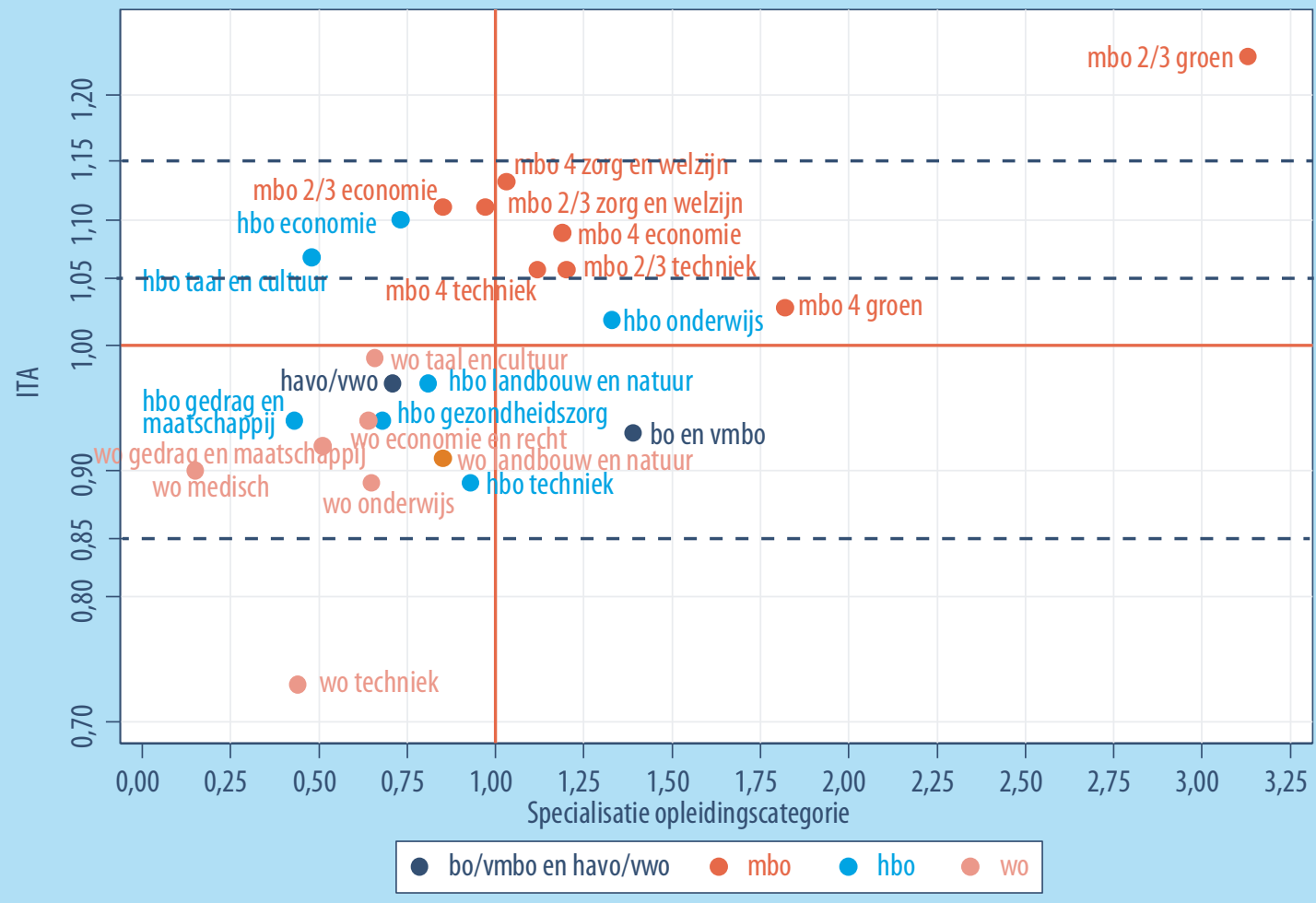




\section{Colofon}

( ) Researchcentrum voor Onderwijs en Arbeidsmarkt Niets uit deze uitgave mag op enige manier worden verveelvoudigd zonder voorafgaande schriftelijke toestemming van de directeur van het ROA.

Researchcentrum voor Onderwijs en Arbeidsmarkt

Maastricht University

School of Business and Economics

secretary-roa-sbe@maastrichtuniversity.nl

www.roa.n

\section{Vormgeving}

ROA secretariaat, Maastricht

juni 2018 